\title{
Assessing the Social Benefits of Tree Planting by Smallholders in Vietnam: Lessons for Large-Scale Reforestation Programs $\odot$ a
}

\author{
Pamela McElwee and Tran Huu Nghi
}

\begin{abstract}
In recent decades, Vietnam has embarked on several ambitious projects, including restoration of coastal mangroves and the expansion of national forest cover through large-scale tree planting efforts. Much of the work is being carried out by individual households, who now likely control a majority of planted productive forest land. Yet despite the strong role for smallholders, questions have been raised about the social benefits of their participation, and insufficient attention has been paid to whether these programs are truly aimed at restoration or more narrowly at plantation development only. This paper assesses several of Vietnam's recent tree-planting projects against the Society for Ecological Restoration's standards, particularly around social benefits, and concludes that Vietnam is failing on most measures, ranging from stakeholder engagement to natural capital benefits. Overall, smallholders mostly view the tree planting projects in terms of financial benefits from short rotation cycles for pulp and woodchip mills, which offer low value, few social benefits, and little ecological restoration potential. The paper argues that Vietnam would benefit from more engaged restoration activities that pay attention to social benefits for smallholders, ensuring more long-term sustainability for both people and forests.
\end{abstract}

Keywords: Asia, participation, plantations, reforestation, social benefits

\section{\$) Restoration Recap *}

- Much restoration work worldwide involves tree planting by smallholders. However, there is often insufficient assessment of the social benefits they receive from participation.

- Vietnam has implemented several large-scale tree planting programs in the past decades, carried out by smallholder households. By evaluating these programs against the Society for Ecosystem Restoration Social Benefits Wheel, we show that a range of potential social benefits are not being realized.

- While these programs have expanded overall forest cover, the benefits to individual households have been limited to economic ones, and there have been negative impacts in several areas, like community wellbeing and insufficient attention to natural capital and ecosystem services.

- Other countries wishing to implement large-scale tree planting by smallholders can take lessons from Vietnam, such as diversifying trees planted, particularly where areabased targets are used; encouraging more bottom-up stakeholder involvement; better monitoring and evaluation; and focusing on longer-term sustainability beyond short-term tree planting cycles. $s$ we move into the UN Decade of Ecological Restoration, new global efforts to increase forest cover are

Color version of this article is available through online subscription at: http://er.uwpress.org

(2) This open access article is distributed under the terms of the CC-BYNC-ND license (http://creativecommons.org/licenses/by-nc-nd/3.0) and is freely available online at: http://er.uwpress.org

Ecological Restoration Vol. 39, Nos. 1-2, 2021

ISSN 1522-4740 E-ISSN 1543-4079

(O2021 by the Board of Regents of the University of Wisconsin System. expanding through the Bonn Challenge, Trillion Tree plan, and other initiatives. However, these ambitious goals will require finding the most appropriate models for replication to achieve success (de Jong 2010, Brancalion and Chazdon 2017); therefore, it is useful to examine the social outcomes of previous large-scale restoration and reforestation initiatives. In particular, forest landscape restoration (FLR) involving smallholders (those with land holdings of 10 ha or below) holds promise in combining attention to livelihoods with provisioning of ecosystem services (Chazdon et al. 2017). At the same time, there may be potential adverse impacts on smallholders when restoration initiatives do 
not pay sufficient attention to social benefits (Adams et al. 2016, Holl 2017).

Vietnam is a particularly useful case study, as several sizable tree planting and restoration programs over the past 30 years have expanded forest cover from a low point of 9.4 million ha in 1990 to an estimated 14.6 million ha in 2020 (Meyfroidt and Lambin 2008, SRV 2020). Much of the work has been carried out by smallholder households, who now control somewhere between $40-70 \%$ of the country's planted forest area, depending on how land 'ownership' is classified (World Bank 2019, MARD 2020). This is in contrast to other countries, in which large-scale plantation establishment (often by governments or businesses) has come at the expense of local peoples, including displacement and other negative socio-economic impacts (Malkamäki et al. 2018). The lessons learned from Vietnam's example could therefore provide useful information for other countries seeking to use smallholders in their own restoration interventions.

Yet there have been few comprehensive assessments of these tree planting initiatives in Vietnam, how they relate to goals for FLR, and what their social impacts have been. Using the Society for Ecological Restoration (SER) international standards, and particularly the new Social Benefits Wheel as a template (Gann et al. 2019), we evaluate Vietnam's programs with a focus on social outcomes. As we show, while Vietnam's tree planting projects have increased overall forest cover, this should not be the only metric on which they are judged. Our findings indicate that on many social benefits measures, outcomes have been more disappointing and many potential benefits of FLR unrealized. We conclude our assessment with some recommendations that would aim at more socially beneficial interventions for smallholders with improved restoration outcomes.

\section{Background: Smallholder Reforestation and Social Benefits}

Many countries have engaged in extensive tree planting, reforestation and FLR schemes in recent years (Adams et al. 2016), leading some to make a "forest transition", reversing trends away from deforestation and towards forest expansion (de Jong 2010, Rudel et al. 2020). But the role of smallholders as drivers of these transitions is not well-understood (Meyfroidt et al. 2018), in part because they engage in a number of models of tree planting (including agroforestry, scattered trees, and concentrated plantations) that are difficult to generalize (Pokorny et al. 2010, Midgley et al. 2017, Ota et al. 2020). Consequently, national trends in forest transitions do not usually provide sufficient understanding of motivations for smallholder participation (Rudel et al. 2020).

More localized case studies suggest that major barriers to participating in both FLR and general tree planting include insecure land tenure (McClain et al. 2018), competition with agriculture (Ota et al. 2020), and poor governance and corruption (Le et al. 2012). Smallholder engagement often requires specific capabilities, including financial capital and long-term planning (Pokorny et al. 2010), and structured incentives, such as access to markets, subsidies and extension (Chazdon et al. 2017). Other proactive interventions for improving smallholder engaged FLR outcomes include a focus on capacity development and training (Bloomfield et al. 2019) and granting of community tenure rights and support (Erhbarg et al. 2020). The long-term engagement and willingness of smallholders is also dependent on the perceived benefits they receive, and existing programs show mixed results in terms of livelihood improvements (Adams et al. 2016, Malkamäki et al. 2018, Brancalion and Holl 2020). Many of these potential success factors and barriers are embedded in the SER Social Benefits Wheel, which was developed to provide an easy-to-adapt template reflecting best-practices and standards (Gann et al. 2019) (Figure 1).

\section{Methods}

We conducted an extensive literature review in Web of Science to find articles that assessed the recent tree planting and FLR projects in Vietnam in a two-step process: first identifying general reports through keywords, resulting in 149 studies (step 1: see supplementary material), and then reading these studies to look for reference to different social benefits, drawing on the broad categories of the SER Social Benefits Wheel (step 2). While the Wheel is meant to be flexible, and components can be added or subtracted depending on the project (Gann et al. 2019), the broad categories that make up the template are well-supported in the general literature, so we kept our focus to these six types. For each of the categories, we compiled examples drawn from the pool of studies, looking for both positive and negative examples, as noted in Table 1 and discussed more fully below.

\section{History of Approaches to Tree Planting and FLR in Vietnam}

Before turning to our assessment of the social benefits of tree planting programs in Vietnam, we provide a brief overview of policies and programs that have been used to encourage expansion of forest cover and ecological restoration over the past few decades.

\section{Early History of Tree Planting Programs and Projects}

One of the earliest tree planting campaigns in Vietnam began in 1959, when President Ho Chi Minh inaugurated a New Year's tree planting tradition. After suffering major damage to the forestry sector during the US-Vietnam War, the reunified government nationalized all forests, and many areas were over-logged to provide wood for war reconstruction or foreign exchange (McElwee 2016). A post-war push 


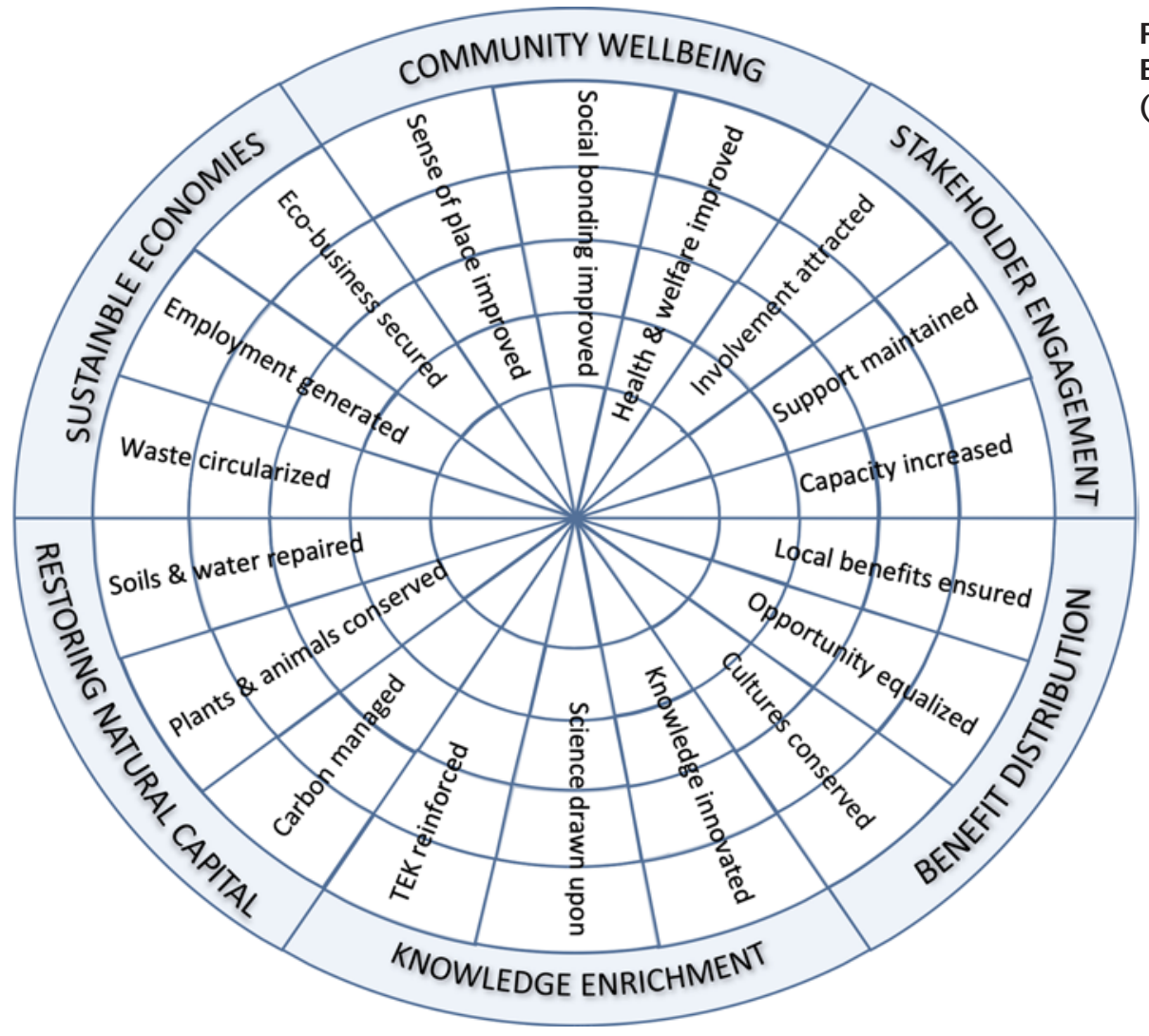

Figure 1. Social Benefits Wheel for Evaluating Restoration Projects (Source: Gann et al. 2019).

for expanded reforestation efforts came from international donors like the World Food Program, who sponsored a major tree planting project in the late 1970s named "PAM", investing US $\$ 160 \mathrm{~m}$ to plant nearly 450,000 ha of forest (Ministry of Forestry 1991). Smallholders in denuded areas of the country were provided with food or cash and tree seedlings; however, the households who participated did not get rights to the trees that they had afforested.

Area-based targets were first suggested in the early 1980s, and a Forest Protection and Development Law of 1991 categorized all forestland into three types (special-use, protection, and production forests), laying the groundwork for different reforestation/restoration priorities. However, there was little investment until 1992, when the first national reforestation program began, known as the 327 Project. The program invested around US $\$ 68 \mathrm{~m}$ per year for five years, with about $45 \%$ of funding slated for afforestation and the rest for forest rehabilitation (Nguyen 1995). These efforts started to expand forest cover but garnered considerable criticism for having prioritized wood production over food security, and for relying heavily on exotic trees such as eucalyptus and acacia (de Jong et al. 2006).

\section{Expanding Nationwide Reforestation Incentives}

The 327 Program laid the groundwork for a National 5 Million Hectare Reforestation Program (5MHRP) that ran from 1998-2010, which dramatically increased both investment levels and ambitions. Over 12 years, the 5MHRP spent more than US $\$ 1.5$ billion from the state budget, donor aid, and the private sector for three primary goals: to increase overall forest cover to $43 \%$; to use forestry as a driver of economic growth in rural areas; and to increase the supply of wood (Nguyen and Gilmour 1999). Of the 5 million hectares targeted, 2 million were to be protected forests, while the remaining were for wood production (MARD 2011). While Decision 661 establishing the program had FLR-oriented goals in calling to "ensure environmental security, reduce natural disasters, increase the capacity of water generation and preserve the source of genes and biological diversity" in reality, it fell short in meeting these ambitious ideals (SRV 2005). The 5MHRP involved smallholders by paying them for protection of rehabilitating and regenerating areas or by subsidizing them to plant trees (Sunderlin and Huynh 2005). The 5MHRP was often combined with Forest Land Allocation (FLA) policies to provide land tenure certificates to degraded lands, requiring that recipient households plant tree seedlings on the land. After 12 years, the final outcomes were re- and afforestation on 2,450,010 ha of land and natural regeneration supported on 1,686,350 ha, failing to meet stated targets for both categories (MARD 2011).

\section{Recent Policies and Pledges}

Since the conclusion of the 5MHRP, the 2011-2020 Forest Development Plan targeted a further increase in forest cover to $44-45 \%$ of total land, or 15.1 million ha by 2020 , although this was not achieved, and more recent goals have been reduced to $42 \%-42.5 \%$ forest cover (SRV 2020). 
Table 1. Positive and negative impacts of Vietnam's afforestation, reforestation, and restoration programs.

\begin{tabular}{|c|c|c|}
\hline Social Benefits & Indicators of Positive Impacts & Indicators of Negative Impacts \\
\hline $\begin{array}{l}\text { Stakeholder } \\
\text { engagement }\end{array}$ & $\begin{array}{l}\text { - Recipients of land tenure certificates more engaged } \\
\text { - (Renumerated) labor provided for protection } \\
\text { programs }\end{array}$ & $\begin{array}{l}\text { - Top down management by government offices } \\
\text { - Little independent decision-making by participating } \\
\text { households }\end{array}$ \\
\hline $\begin{array}{l}\text { Benefit } \\
\text { distribution }\end{array}$ & $\begin{array}{l}\text { - Households able to claim secure land tenure } \\
\text { certificates } \\
\text { - Some (minimal) mixing of food crops and tree } \\
\text { seedlings }\end{array}$ & $\begin{array}{l}\text { - Early programs led to few direct household benefits } \\
\text { - Projects tend to favor households with land and capital } \\
\text { assets } \\
\text { - Concerns about rising income inequality and land stratifi- } \\
\text { cation with poor households least likely to benefit } \\
\text { - Ethnic minorities less likely to benefit } \\
\text { - Gender differentials in access to benefits }\end{array}$ \\
\hline $\begin{array}{l}\text { Knowledge } \\
\text { enrichment }\end{array}$ & $\begin{array}{l}\text { - Voluntary owner associations can be set up } \\
\text { (though not widespread) }\end{array}$ & $\begin{array}{l}\text { - Little knowledge or training associated with programs } \\
\text { - Lack of use of local knowledge } \\
\text { - Targets often not met due to information barriers } \\
\text { - Little awareness of damaging practices }\end{array}$ \\
\hline Natural capital & $\begin{array}{l}\text { - Improvements in soil quality (nitrogen, carbon } \\
\text { storage) } \\
\text { - Protection from storm surge, benefits of } \\
\text { windbreaks } \\
\text { - Biodiversity improvements dependent on species } \\
\text { and scale } \\
\text { - Can be motivated by payments or subsidies }\end{array}$ & $\begin{array}{l}\text { - Many plantations managed poorly for natural capital } \\
\text { - Some plantings inappropriate in vulnerable areas } \\
\text { (typhoons) } \\
\text { - Some replacement of natural forests by less diverse } \\
\text { plantations } \\
\text { - High biodiversity plantings require more land and longer } \\
\text { rotations }\end{array}$ \\
\hline $\begin{array}{l}\text { Sustainable } \\
\text { economies }\end{array}$ & $\begin{array}{l}\text { - Profitability varies, dependent on land \& labor } \\
\text { prices and subsidies } \\
\text { - Flexibility as to harvesting time } \\
\text { - Subsidies are strong motivation } \\
\text { - Certification can raise economic benefits }\end{array}$ & $\begin{array}{l}\text { - Subsidies can encourage forest conversion } \\
\text { - Certification is difficult to get }\end{array}$ \\
\hline $\begin{array}{l}\text { Community } \\
\text { wellbeing }\end{array}$ & - Some potential shared ecosystem services benefits & $\begin{array}{l}\text { - Community management can take more labor } \\
\text { - Can disrupt traditional systems of community land } \\
\text { management }\end{array}$ \\
\hline
\end{tabular}

Program 147 (from 2007-2015) encouraged the expansion of market activities and infrastructure like roads, forest product processing, and factories, aiming to diversify forest actors beyond the traditional role of the state, and to expand production forests, which by 2019 comprised $53 \%$ of total forest area (the rest remain for protection purposes, mostly managed by different levels of government).

Within the 7.8 million hectares of forests managed for production, 4.3 million ha are classified as 'natural' while 3.5 million ha are "planted" (MARD 2019). While the former does include forests established through reforestation and enrichment planting, the latter refers almost exclusively to plantations and use of non-native species, including Acacia mangium, Acacia auriculiformis or a hybrid of both (for timber and woodchips), Eucalyptus camaldulensis (usually for paper pulp), or Casuarina equisetifolia (planted as coastal windbreaks). Acacia plantations alone now comprise $15-20 \%$ of total land area in some provinces (Tran et al. 2020), a huge jump from only 66,000 ha of nationwide estimated in 1992 (Nambiar et al. 2015).

For planted production forests, smallholders comprise the largest group of land managers, with nearly 1.6 million ha under their control (MARD 2020), while State Forestry Companies (formerly para-statal enterprises now privatized to commercial companies) control the second largest area. These companies tend to produce more timber than smallholders, who mostly focus on short rotation harvesting for woodchips and pulp and paper mills (Maraseni et al. 2017). The government estimates that up to 5 million people are now employed in a number of forest-related enterprises and industries (e.g., growing, processing, furniture production, etc.) (SRV 2020), and that smallholder forestry contributes at least US $\$ 500$ million a year (Midgley et al. 2017).

Vietnam's Nationally Determined Contribution (NDC) to the Paris Agreement in 2016 also made a pledge to add 20,000 to 50,000 ha of additional restored and afforested mangroves. Mangrove restoration in coastal areas has been encouraged and funded through multiple sources in recent years, including donors, the Vietnam Red Cross, and others, often driven by interest in disaster risk reduction (Kumar et al. 2015). Some provinces have implemented specific policies to encourage mangroves in mixed shrimp production ponds, as conversion for aquaculture is a major driver of mangrove loss (Nguyen et al. 2017). However, these models have been complicated by land tenure issues, because many households taking part hold yearly contracts with a State Forest Company (which officially owns the land), limiting households' decision-making power (Tran et al. 2012). 
The remaining $47 \%$ of the forest estate remains classified as either watershed protection or special-use forest (essentially equivalent to protected areas), often in degraded condition that would benefit from restoration (Rizzetti et al. 2018). While the 5MHRP did invest in restoration and natural regeneration in protected forests, this has been offset by continued loss, due to encroachment, illegal exploitation, fire or other reasons (Cochard et al. 2020). Some donor-funded projects have invested in FLR for these natural/protected forests but have shown only modest results (Mansourian and Vallauri 2014, Rizzetti et al. 2018). While natural forests are usually under government tenure, households can protect these lands through incentive payment programs, including Payments for Forest Ecosystem Services (PFES), with funding coming from payees like hydropower companies. However, funds tend to be modest (\$5-10 per ha), and do not have a specific requirement that households use the money for afforestation or restoration. There is no strong evidence that national forest quality has improved since PFES programs began (Cochard et al. 2020), and because most of the PFES programs have not involved direct restoration or tree planting, they are not assessed in our review below.

Attention to sustainable forestry has increased in recent years, particularly a target program with national funding that began in 2017, as well as a revised Forestry Law of 2017, which aimed to regulate logging in natural forests and promote more sustainable forestry in general. The guidelines included a call to "Improve the production output and quality, promote the value of each forest type, increase the value of production forests per each area unit; contribute to meeting the requirements of natural disaster mitigation, ecological and environmental protection, response to climate change and sea level rise; create jobs, increase income, contribute to hunger eradication and poverty alleviation, improve livelihood for people working in the forestry sector, closely align these activities with the process of building new rural areas, maintaining national defense, security, social order and safety" (SRV 2017). As a priority moving forward, $15 \%$ of "forest ecosystem degradation areas" are to be restored, particularly in special-use forests, as well as expanding this category by 100,000 hectares.

\section{Social Outcomes of Smallholder Tree Planting}

Most evaluations of the last 30 years of tree planting and other restoration projects in Vietnam have not adequately examined either social or environmental impacts; instead, programs have primarily been evaluated only by whether or not an increase in forest cover has occurred or program targets were achieved (World Bank 2010, MARD 2011). This is despite the fact that 5MHRP had numerous social and environmental goals, none of which were ever adequately measured, and more recent policies like the 2017 Forestry Law have emphasized sustainable forestry without clear indicators to measure success. We compared reported outcomes from our literature review to the six key areas of the SER "Social Benefit Wheel" derived from international experience. These components also particularly align with goals for Vietnam's forest sector in the 2011-2020 Forestry Development Plan, which called for increased education, scientific investment, economic outputs, and community benefits (Decision 57-QD-TTg).

\section{Stakeholder Engagement}

Stakeholder engagement refers to attracting the involvement and support of diverse participants as well as increasing their capacity to improve effectiveness (van Oosten 2013, Lazos-Chavero et al. 2016). Stakeholders can be engaged in multiple ways, ranging from site selection and choice of species to providing labor, as well as overall governance. Yet within Asia, there has been a trend towards state forestry agencies recentralizing their power through reforestation and restoration actions in recent years, curtailing stakeholder engagement (Barr and Sayer 2012).

Vietnam is facing the same challenge, despite narratives that often center around the program's use of smallholders, implying it must be participatory. In fact, most of the major tree planting projects have been managed from the topdown (Ohlsson et al. 2005), and there were no reports that directly assessed and demonstrated increased smallholder capacity. Indeed, early programs saw some households refusing to participate as they did not see what benefits they would receive (Clement and Amezaga 2008), although benefits improved over time as land tenure certificates became part of the restoration packages. In the 5MHRP, Project Management Boards at the provincial level, aided by technical support from agriculture and forestry agencies, often made most decisions, such as which species to plant (Tran et al. 2014b). There was little opportunity for decision-making by households, who were not consulted on their preferences nor given options to be involved in more ecologically focused restoration activities (McElwee 2009). For most, their primary participation was to provide labor for initial tree planting, for tending stands, for protecting forests from fires and pests, and for harvesting trees (Harwood et al. 2017), and a lack of capacity for more extended engagement was reported in several projects (Yamanoshita and Amano 2012). Even models more explicitly focused on co-management between communities and the state have tended to be dominated by decision-making by government agencies, with little input from participating households (Tran et al. 2014c), although some mangrove restoration projects funded by donors have achieved more comprehensive participation in planning of afforestation actions and monitoring (Nguyen et al. 2016a). 


\section{Benefits Distribution}

Globally, livelihood benefits from afforestation and restoration depend on the type of program; for example, large-scale plantations run by outside investors have been associated with higher levels of poverty and diminished livelihoods (Malkamäki et al. 2018), while more modestscale FLR programs have better balanced social and environmental benefits (Adams et al. 2016, Mansourian and Vallauri 2014). Vietnam's case indicates that there are potential benefits associated with smallholder tree planting, but also evidence of rising inequalities.

The early programs often did not bring many individual benefits to households, because they were not the owners of the land that was afforested and therefore had no right to forest produce. Program 327 also resulted in the conversion of some upland crop fields under de facto use into forests without providing alternative subsistence means or support, and in those cases, households often chose participation in tree planting as a "least bad choice" when soil infertility and pro-afforestation policies made it too difficult to continue annual cropping on sloping lands (Clement and Amezaga 2008). In other areas, afforestation projects resulted in displacement of activities like grazing into other nearby lands (Yamanoshita and Amano 2012). Competition between food production and expanding or maintaining forests has been a common problem (Khuc et al. 2020), especially in areas where industrial cash crop production, like cassava, is encroaching on natural forest (Rizzetti et al. 2018). Such competition with profitability of agriculture and food security argues for combinations of agroforestry in restoration programs, but for various political and economic reasons this has not been widespread (Simelton et al. 2017).

The expansion of markets for forest products have brought more economic benefits in recent years, often dependent on access to processing facilities since most wood is sold by households as unprocessed (e.g., as stripped poles). Income provided by plantations has been reported to range from around $5 \%$ to $25 \%$ of household livelihoods, depending on location (Sandewall et al. 2010, Sikor 2011, Dang et al. 2018). However, reports have also indicated that households needed to have endowments-like labor and land-before they could engage in afforestation, thereby favoring better-off households from the start (McElwee 2009, Sikor and Baggio 2014).

Participants in the most recent reforestation programs often received land tenure certificates depending on the forest type, and households have sometimes used afforestation projects as a means of claiming land, rather than being solely motivated by trees themselves (McElwee 2016, Nguyen and Masuda 2018). Wealthier households appear more able to claim land via reforestation programs; in multiple studies, the poor have been the least likely to receive forest land allocation (Sowerwine 2004, Sikor and
Nguyen 2007). McElwee (2009) recorded increasing land stratification between rich and poor after the 5MHRP in one central Vietnam province, while another study in a national park buffer zone in northern Vietnam demonstrated that government elites were the prime beneficiaries of the project (Dressler et al. 2013). Sikor and Baggio (2014) report that more than half of the surveyed households in a study site in the South-Central Coastal region did not have any forestland, while a minority of $10 \%$ controlled 20 ha or more. Those with little to no land but living near forest plantations often find themselves doing seasonal laboring, such as stripping poles at harvest time (Thulstrup 2014), or perhaps being allowed to interplant crops for 1-2 years in exchange for planting the tree seedlings for these richer households (Dressler et al. 2013). In one study in Quang Nam province, acacia plantation expansion was driven by the ethnic Vietnamese (Kinh) majority, while the local ethnic minority group was slower to develop plantations, and in some cases signed over land use and harvesting rights to others (Thulstrup 2015).

There are also indications of gender impacts, as women's interests in tree planting often focus on multifunctional agroforestry, food security, and fuelwood production (which have tended to be de-emphasized in reforestation projects), while men have sought out income increasing opportunities (Nguyen et al. 2016b, Villamor et al. 2017). Women have often provided labor for tree planting within households, but rarely have controlled decision-making about the forest plot (Richards 2019). Additionally, in one case recorded in Central Vietnam, women lost access to common lands they had used for non-timber forest product (NTFP) collection when lands were converted to plantations (McElwee 2009).

\section{Knowledge Enrichment}

Knowledge enrichment refers to achieving a balance of scientific research and application of local and traditional knowledge, as well as opportunities for participants to expand their capacity (Chazdon et al. 2017, Bloomfield et al. 2019). Yet engagement of local knowledge has been minimal in Vietnam, and even the application of scientific knowledge to restoration projects has encountered difficulties. For example, a study in Kien Giang province on mangrove reforestation, where households were allocated protection forest on which $70 \%$ forest cover must be retained, noted that no technical guidance was offered to households, only financial support (Nguyen et al. 2017). Consequently, few households undertook the reforestation and some households wanted to return the allocated lands back to the government. In other studies, only around $2 / 3$ of forest lands allocated to households were actually planted with trees, either due to technical or information barriers (Dinh et al. 2017, Nguyen and Masuda 2018).

For acacia plantations in particular, there is insufficient knowledge conveyed to encourage smallholders to avoid 
unnecessary and damaging practices, like burning litter or ploughing after harvest (Nambiar et al. 2015). Household surveys reveal that smallholders have little knowledge about the technical needs of acacia, such as use of pesticides or how to control disease (Nguyen et al. 2014). While extended-rotation plantations and native species often provide more economic and environmental benefits, households are often unwilling to undertake them because of lack of information (Rizzetti et al 2018).

Additionally, recent laws allow for voluntary forest owner associations to be established to support members in information and training but are not yet widespread (Zhunusova et al. 2019). There were also few studies found on positive use of traditional knowledge to improve restoration outcomes in Vietnam, with only one example in the literature from a donor-funded mangrove afforestation project where local ideas of how to use fencing to ensure mangrove survival were implemented (Nguyen et al. 2016a). There were however several negative examples of afforestation projects that farmers objected to and for which their local knowledge was not used (Gomiero et al. 2001, Clement and Amezaga 2009, Nguyen 2009).

\section{Natural Capital}

Natural capital provisioning from restoration and reforestation depends in part on species selected and how they are planted and managed (Lamb 2018). SER standards refer to soil and water improvements, increases in biodiversity, and improved carbon sequestration as positive natural capital outcomes. Vietnam's programs provide mixed results on these measures, and many of the natural capital benefits have been presumed, rather than systematically assessed and monitored (Clement and Amezaga 2008).

Although some articles noted improved overall ecosystem services as compared with previous degraded lands after afforestation (Paudyal et al. 2020), most projects have not been specifically designed with ecosystem service provisioning in mind. Nonetheless, because much of Vietnam's afforestation has been on highly degraded and damaged soils, resulting from war (Harwood et al. 2017) or from previous overuse (Nguyen and Masuda 2018), in these cases, restoration has improved conditions, and even monocrop acacia plantations can improve soil properties, particularly around nitrogen fixation and soil carbon storage (Tran et al. 2014a, Sang et al. 2013). Protection from coastal erosion and storm surge has also been noted in mangrove restoration projects (Hai et al. 2020), and plantations can serve as windbreaks to prevent soil erosion, but have been less effective in improving water supplies (Simelton and Dam 2014). High carbon benefits from replanting of mangroves were also recorded by several studies (Pham et al. 2017), with both manually planted and naturally regenerated mangroves showing success (Nam et al. 2016).

Management practices play a large role in determining natural capital benefits; for example, short rotation plantation cycles combined with a tendency to remove bark and litter for fuelwood can result in loss of nutrients (Nguyen et al. 2018). Chemical fertilizer use, burning of litter, and ploughing during planting further reduces ecosystem services benefits, and sustainable production in the future depends on discouraging these practices (Harwood et al. 2017). Experimental fields show that retaining slash and following best practices increases soil organic $\mathrm{C}$ and $\mathrm{N}$ in successive rotations ( $\mathrm{Vu}$ et al. 2014).

Biodiversity benefits have been minimal in acacia plantations, but better in restoration projects with a deliberate focus (Millet et al. 2013), and particularly in mangrove restoration, which can provide a home to multiple species such as crabs and fish (Kumar et al. 2015). Projects for natural regeneration, enrichment planting and use of native species for reforestation have shown the best natural capital and biodiversity outcomes (Woo et al. 2011, Crowther et al. 2020). However, native species often require rotations as long as 30 years or more, even though the price for timber is considerably higher, making them financially challenging (Šálek and Sloup 2012, Nguyen et al. 2014, Nguyen and Masuda 2018). Only households with larger land sizes over 5 ha were able to produce on extended rotations, according to one study (Zhunusova et al. 2019), and many restoration initiatives have excluded smallholders with holdings of less than 3 ha for this reason (Rizzetti et al. 2018).

Negative natural capital outcomes have been noted in some studies as well. Acacia plantations are at risk from natural hazards, particularly in central Vietnam where typhoon activity is high (Thulstrup et al. 2013, Zhunusova et al. 2019) and in the northern mountains where cold snaps can kill young trees (Le et al. 2016). In Kien Giang, use of Rhizophora apiculata encouraged by reforestation projects replaced a more diverse mangrove ecology, leading to less resilience and increased coastal erosion as Rhizophora roots were less deep-rooted and could not withstand strong wave action (Phong et al. 2017). Other examples of plantation expansion into existing natural forests have been noted as well, often dependent on local land tenure situations and land market prices (Cochard et al. 2020, Paudyal et al. 2020).

\section{Sustainable Economies}

The smallholder forestry sector in Asia can be quite profitable, but the literature notes the need to ensure long-term economic sustainability of projects. Vietnam's programs have a mixed record with economic success; many are low-value enterprises, and their long-term sustainability is unknown (Sandewall et al. 2015). Early afforestation programs did not allow households to profit from the sale of forest products or did not create a sufficient market for wood (McElwee 2009). Only until the 2000s did economic incentives combined with more secure land tenure rights serve to spur increased smallholder benefits. 
The economic value of plantations varies depending on whether households need to rent land, hire labor and/ or borrow money for investment, and if they receive any government subsidies for planting or protection (Tran et al. 2020). Smallholder incomes from plantations range widely, depending on location, with an average around USD $\$ 2,400 /$ ha for a short rotation, not including expenses (which can comprise 10-20\% of income) (Dinh et al. 2017). Forest plantations do provide flexibility in terms of harvesting, in that households can use their trees as a bank; selling standing trees is common, and buyers are responsible for harvesting and transport (Sikor 2011).

For households with adequate land, particularly lands not suited for agriculture, such returns are sufficient to drive participation. In early years in the 1990s and 2000s, households could often occupy and claim unused lands, but this route is no longer available. Many smallholders now have to purchase land if they want to expand plantations, which favors the wealthier. Households with more labor availability are also more likely to plant trees (Dinh et al. 2017), and their ability to access loans has also been a positive indicator of afforestation (Sikor and Baggio 2014). The costs of up-front investment are difficult for poor households and those in more remote areas away from markets, so subsidies remain a major incentive in various policies. Households that participated in 5MHRP for example received nearly $\$ 100 \mathrm{USD} / \mathrm{ha}$ for initial planting and $\$ 3-5 /$ ha a year for protection, and many households would not have undertaken afforestation without the support (McElwee 2009). However, this subsidy approach can bring negative impacts as well. For example, in Kien Giang province, local authorities encouraged mangrove planting through subsidies for up to three years to households. Participants actually cut existing mangroves down to replace them with seedlings in order to receive the subsidy, thereby leading to loss of mature diverse forests (Phong et al. 2017).

Given these challenges, one possible source of new financing might be payments for ecosystem services (Hoang et al. 2013, Crowther et al. 2020), as farmers show interest in increasing biodiversity if provided with subsidy payments (Nghiem 2012). Some studies indicated willingness to pay from beneficiaries, particularly around mangrove restoration (Pham et al. 2018) or potential funding from global carbon markets (Kumar et al. 2015), but such approaches have been theoretical only, as the existing PFES policy is not operational in mangroves nor does it pay for carbon (McElwee et al. 2019). Overall, evidence suggests that existing low subsidies and other payments cannot financially compete with the current plantation boom that favors short rotations (Cochard et al. 2020) or competition from shrimp production that discourages mangrove restoration (Tran et al. 2012). Consequently, certification might be an additional option to extend financial sustainability to Vietnam's smallholder plantations, as prices paid are substantially higher (Frey et al. 2018). However, the cost to receive certification is a significant barrier to expanded participation, and subsidies are usually needed to get farmers to consider it (Nguyen et al. 2019). Smallholders also evince little engagement with or understanding of the environmental benefits of certification (Nguyen et al. 2015).

\section{Community Wellbeing}

There has been increased emphasis in the forest restoration literature on realizing collective benefits, including support for community engagement (Chazdon et al. 2017). However, despite having several forest protection co-management and community forestry models, few studies examined communal social benefits (as opposed to individual ones) from tree planting programs, such as recreational opportunities provided by reforested areas (Tran and Brown 2019). Overall, outcomes have generally been mixed for community forestry and co-management models, which have suffered from lack of active participation (Tran and Sikor 2006, Yamanoshita and Amano 2012). Collective participation in regeneration and protection can actually take more labor than individual smallholder reforestation, concluded one study, due mostly to time spent in community meetings (Tran et al. 2014b). There have also been concerns raised that the various afforestation programs have disrupted local systems of land management, such as management of commons, in favor of individual land tenure (Clement and Amezaga 2009). Related to this, ethnic minority communities, who tend to have stronger community and cultural traditions, have been less likely to participate in Vietnam's afforestation programs (Dinh et al. 2017, Sowerwine 2004).

\section{Discussion: Evaluating Vietnam's Efforts}

Overall, the social impacts and benefits of Vietnam's extensive recent campaigns for tree planting and forest restoration have been modest across all six social issue areas assessed (Table 1). The only major social benefit category with evidence of generally positive impacts was in economics, and even there, often those who were already better off seem to have benefitted the most, leading to a risk of inequality. Across other categories, like knowledge and capacity, there is little evidence of substantial positive outcomes. There have also been discrepancies in who received social benefits, with fewer benefits to ethnic minorities, women, and the poor. There have also been negative outcomes reported, including inappropriate afforestation in typhoon-vulnerable areas, replacement of natural forests by plantations, and disruptions of community land management systems.

What accounts for these uneven social outcomes? It is likely that the approach used in Vietnam-area-based targets combined with limited and short-term financial subsidies to smallholder households-has resulted in use of fast-growing species like acacia, with little attention to 
the more comprehensive social and environmental issues that should be addressed in FLR. Such area-based targets were mostly designed by government and donors, and do not reflect input from local levels, often missing the importance of multiple qualitative objectives, including ecosystem services provisioning or more sustainable livelihoods. Even where projects have attempted to expand restoration goals through natural regeneration and native species, they have faced significant challenges in engaging the smallest landowners and the poor (Rizzetti et al. 2018). At the same time, deforestation and degradation in natural forests is continuing even as plantation forests expand (Cochard et al. 2020); as a result, the tree planting projects do not appear to be tackling the drivers of forest loss overall (Holl and Brancalion 2020).

Other key take-aways from our review of Vietnam's restoration programs are the lack of monitoring, followup assessments, and good statistical data. There is inconsistency between government reports on basic data, like number of smallholders engaged in restoration. Few projects are assessed after the fact to determine even basic tree survival rates, let alone more complicated social benefits (Hai et al. 2020). As a result, much of our assessment has relied on local case studies, with little nation-wide analysis or evaluation. Without access to such data, it is difficult to draw conclusions about the benefits and costs of tree planting programs, and future projects will need to plan regular evaluation into their models (Erbaugh and Oldekop 2018). This is not a problem confined to Vietnam: most evaluations of restoration activities worldwide have been of area restored or number of trees planted, what Mansourian et al. (2017) label an "effort approach". Focusing not on effort, but instead on impact, determined through comprehensive assessments, would require better evaluation of social and ecological benefits for different sectors and actors, as we have attempted to do here.

In sum, if the various tree-planting and restoration projects in Vietnam had to be redesigned with the benefit of hindsight and guidance of the SER wheel, our analysis suggests the need for bottom-up goals and priorities (rather than top-down area-based targets), more subsidies, technical support and capacity-building (to encourage longergrowing native species and more sustainable household forestry models), and better assessments to enable adaptive management and readjustments over time.

\section{Conclusions: Lessons for Smallholder Tree Planting Programs}

How to successfully undertake forest restoration initiatives to achieve large-scale targets remains a key question, particularly in Southeast Asia, where biophysical conditions for restoration are high, but social, economic and political factors remain challenging (Zeng et al. 2020). Despite decades of efforts and billions of US dollars spent, and while the country has expanded forest cover and planted millions of trees, the social benefits of these programs have been modest in Vietnam. From our assessment of the literature, the country still has a long way to go in terms of achieving multifaceted, long-lasting, and sustainable ecological and human benefits.

Given these weaknesses, Vietnam should prioritize shifting to more socially and ecologically engaged restoration approaches, and away from simple area-based targets for forest cover. These more engaged approaches would include investments in education and extension, given that knowledge enhancement and capacity outcomes have been weak in programs to date. The current approach of providing short-term planting subsidies but little else has led to questions about long-term sustainability, and future priorities might include extended subsidies focused particularly on ecosystem services provisioning. More engaged restoration activities would also focus on the many potentially positive social outcomes that restoration can bring, from community well-being to more gender-balanced benefits. Yet planners should also acknowledge that multiple goals for restoration can conflict, and not everything can be achieved in the same way (Brancalion and Holl 2020).

Our review indicates that there are also some useful lessons to be learned from Vietnam about how to design programs for large-scale tree planting elsewhere. The involvement of smallholders is extremely important, as they have the capacity and ability to drive significant changes. Yet their ability has been limited by top-down programs, insufficient understanding of their needs and wishes, and shortterm planning. Area-based targets have also led to a focus on exotic and fast-growing species, at the expense of more ecosystem-service oriented restoration. Other countries wishing to expand smallholder reforestation efforts can learn lessons, particularly around the need to link tree planting to local input and for longer-term subsidies to make planting profitable, and to prioritize more ecologically focused restoration that results in multiple individual and collective benefits.

\section{Acknowledgments}

PM's research on tree planting has been supported by the Wenner Gren Foundation for Anthropological Research, a National Science Foundation Dissertation Improvement Grant, the Carnegie Corporation, and a National Science Foundation Grant $\# 1853759$. She would like to thank her research sponsor in Vietnam, the Center for Natural Resources and Environmental Studies of Vietnam National University, and in particular Vo Thanh Giang and Vu Thi Dieu Huong, for their support. NT's work has been supported by Tropenbos International and People and Reforestation in the Tropics: A Network for Education, Research and Synthesis (PARTNERS), funded by the NSF to University of Connecticut. 


\section{References}

Adams, C., S.T. Rodrigues, M. Calmon and C. Kumar. 2016. Impacts of large-scale forest restoration on socioeconomic status and local livelihoods: What we know and do not know. Biotropica 48:731-744.

Barr, C.M. and J.A. Sayer. 2012. The political economy of reforestation and forest restoration in Asia-Pacific: Critical issues for REDD+. Biological Conservation 154:9-19.

Bloomfield, G., P. Meli, P.H.S. Brancalion, E. Terris, M. Guariguata and E. Garen. 2019. Strategic insights for capacity development on forest landscape restoration: Implications for addressing global commitments. Tropical Conservation Science 12: 1940082919887589.

Brancalion, P.H.S. and R.L. Chazdon. 2017. Beyond hectares: Four principles to guide reforestation in the context of tropical forest and landscape restoration. Restoration Ecology 25:491-496.

Brancalion, P.H.S. and K. Holl. 2020. Guidance for successful tree planting initiatives. Journal of Applied Ecology 57:2349-2361.

Chazdon, R.L, P.H.S. Brancalion, D. Lamb, L. Laestadius, M. Calmon and C. Kumar. 2017. A policy-driven knowledge agenda for global forest and landscape restoration. Conservation Letters 10:125-132.

Clement, F. and J.M. Amezaga. 2008. Linking reforestation policies with land use change in northern Vietnam: Why local factors matter. Geoforum 39:265-277.

Clement, F. and J.M. Amezaga. 2009. Afforestation and forestry land allocation in northern Vietnam: Analysing the gap between policy intentions and outcomes. Land Use Policy 26:458-470.

Cochard, R., D.T. Ngo, P.O. Waeber and C.A. Kull. 2017. Extent and causes of forest cover changes in Vietnam's provinces 1993-2013: a review and analysis of official data. Environmental Reviews 25:199-217.

Cochard, R., V.H.T. Nguyen, D.T. Ngo and C.A. Kull. 2020. Vietnam's forest cover changes 2005-2016: Veering from transition to (yet more) transaction? World Development 135:105051.

Crowther, J., H. Zimmer, H.T. Le, T.L. Quang and J.D. Nichols. 2020. Forestry in Vietnam: The potential role for native timber species. Forest Policy and Economics 116:102182.

Dang, T.K.P., I.J. Visseren-Hamakers and B. Arts. 2018. Forest devolution in Vietnam: From rhetoric to performance. Land Use Policy 77:760-774.

Dinh, H.H, T.T. Nguyen, V.N. Hoang and C. Wilson. 2017. Economic incentive and factors affecting tree planting of rural households: Evidence from the Central Highlands of Vietnam. Journal of Forest Economics 29:14-24.

Dressler, W.H., To, P.X. and S. Mahanty. 2013. How biodiversity conservation policy accelerates agrarian differentiation: The account of an upland village in Vietnam. Conservation and Society 11:130-143.

Erbaugh, J.T and J.A. Oldekop. 2018. Forest landscape restoration for livelihoods and well-being. Current Opinion in Environmental Sustainability 32:76-83.

Frey, G.E., F.W. Cubbage, T.T.T. Ha, R.R. Davis, J.B. Carle, V.X. Thon et al. 2018. Financial analysis and comparison of smallholder forest and state forest enterprise plantations in Central Vietnam. International Forestry Review 20:181-198.

Gann, G.D, T. McDonald, B. Walder, J. Aronson, C.R. Nelson, J. Jonson, et al. 2019. International principles and standards for the practice of ecological restoration. Second edition. Restoration Ecology 27:4-46.

Gomiero, T., D. Pettenella, G.P. Trieu and M.G. Paoletti. 2001. Vietnamese uplands: Environmental and socio-economic perspective of forest land allocation and deforestation Environment, Development and Sustainability 2:119-142.

Hai, N.T., B. Dell, V.T. Phuong and R.J. Harper. 2020. Towards a more robust approach for the restoration of mangroves in Vietnam. Annals of Forest Science 77:18.

Harwood, C.E., E.K.S. Nambiar, P.X. Dinh, L.X. Toan and L.T. Quang. 2017. Managing wood production from small grower acacia hybrid plantations on eroded soils in central Vietnam. Australian Forestry 80:286-293.

Hoang, M.H., T.H. Do, M.T. Pham, M. van Noordwijk and P.A. Minang. 2013. Benefit distribution across scales to Reduce Emissions from Deforestation and Forest Degradation (REDD+) in Vietnam. Land Use Policy 31:48-60.

Holl, K. 2017. Restoring tropical forests from the bottom up. Science 355 (6324):455-456.

Holl, K. and P.H.S. Brancalion. 2020. Tree planting is not a simple solution. Science 368 (6491):580-581.

de Jong, W. 2010. Forest rehabilitation and its implication for forest transition theory. Biotropica 42:3-9.

de Jong, W., Do Dinh Sam and Trieu Van Hung. 2006. Forest rehabilitation in Vietnam: realities and future. Bogor: Center for International Forestry Research.

Khuc, Q.V, T.A.T. Le, T.H. Nguyen, D. Nong, B.Q. Tran, P. Meyfroidt, et al. 2020. Forest cover change, households' livelihoods, tradeoffs, and constraints associated with plantation forests in poor upland-rural landscapes: Evidence from North Central Vietnam. Forests 11:548.

Kumar, C., S. Begeladze, M. Calmon and C. Saint-Laurent. 2015. Enhancing food security through forest landscape restoration: Lessons from Burkina Faso, Brazil, Guatemala, Viet Nam, Ghana, Ethiopia and Philippines. Gland, Switzerland: IUCN.

Lamb, D. 2018. Undertaking large-scale forest restoration to generate ecosystem services. Restoration Ecology 26:657-666.

Lazos-Chavero, E, J. Zinda, A. Bennett-Curry, P. Balvanera, G. Bloomfield, C. Lindell et al. 2016. Stakeholders and tropical reforestation: Challenges, trade-offs, and strategies in dynamic environments. Biotropica 48:900-914.

Le, H.D., C. Smith, J. Herbohn and S. Harrison. 2012. More than just trees: Assessing reforestation success in tropical developing countries. Journal of Rural Studies 28:5-19.

Le, N.L., D. Wichelns, F. Milan, C.T. Hoanh and N.D. Phuong. 2016. Household opportunity costs of protecting and developing forest lands in Son La and Hoa Binh Provinces, Vietnam. International Journal of the Commons 10:902-928.

Malkamäki, A., D. D’Amato, N.J. Hogarth, M. Kanninen, R. Pirard, A. Toppinen et al. 2018. A systematic review of the socioeconomic impacts of large-scale tree plantations, worldwide. Global Environmental Change 53:90-103.

Mansourian, S. and D. Vallauri. 2014. Restoring forest landscapes: Important lessons learnt. Environmental Management 53: 241-251.

Mansourian, S., J.A. Stanturf, M. Derkyi and V.L. Engel. 2017. Forest landscape restoration: increasing the positive impacts of forest restoration or simply the area under tree cover? Restoration Ecology 25:178-183.

Maraseni, T.N., H.L. Son, G. Cockfield, H.V. Duy and T.D. Nghia. 2017. Comparing the financial returns from Acacia plantations with different plantation densities and rotation ages in Vietnam. Forest Policy and Economics 83:80-87.

Ministry of Agriculture and Rural Development (MARD). 2011. Báo cáo dự án trông mới 5 triệu ha rừng giai đoạn 19982010. Report on the 5 Million Hectare Reforestation Project 
1998-2010. Hanoi, Vietnam: Ministry of Agriculture and Rural Development.

Ministry of Agriculture and Rural Development (MARD). 2020. Quyết định: Công bố hiện trạng rừng toàn quốc năm 2019. Decision: Announcing the current nationwide state of forests, 2019. Hanoi, Vietnam: Ministry of Agriculture and Rural Development.

McElwee, P.D. 2009. Reforesting 'bare hills' in Vietnam: Social and environmental consequences of the 5 Million Hectare Reforestation Program. Ambio 38:325-333.

McElwee, P.D. 2016. Forests Are Gold: Trees, People and Environmental Rule in Vietnam. Seattle, WA: University of Washington Press.

McElwee, P.D., B. Huber and V.H. Nguyen. 2019. Hybridized outcomes of payments for ecosystem services policies in Vietnam: Between theory and practice. Development and Change 51:253-280.

McLain, R., S. Lawry, M.R. Guariguata and J. Reed. 2018. Toward a tenure-responsive approach to forest landscape restoration: A proposed tenure diagnostic for assessing restoration opportunities. Land Use Policy 103748.

Meyfroidt, P. and E.F. Lambin. 2008. The causes of the reforestation in Vietnam. Land Use Policy 25:182-197.

Meyfroidt, P., R. Roy Chowdhury, A. de Bremond, E. Ellis, K.H. Erb, T. Filatova, et al. 2018. Middle-range theories of land system change. Global Environmental Change 53:52-67.

Midgley, S.J., P.R. Stevens and R.J. Arnold. 2017. Hidden assets: Asia's smallholder wood resources and their contribution to supply chains of commercial wood. Australian Forestry 80:1-16.

Millet, J., N. Tran, N.V. Ngoc, T. Tran and D. Prat. 2013. Enrichment planting of native species for biodiversity conservation in a logged tree plantation in Vietnam. New Forests 44:369-83.

Ministry of Forestry. 1991. Vietnam forestry sector review, Tropical Forestry Action Programme. Hanoi, Vietnam: Ministry of Forestry.

Nam, V.N., S.D Sasmito, D. Murdiyarso, J. Purbopuspito and R.A. MacKenzie. 2016. Carbon stocks in artificially and naturally regenerated mangrove ecosystems in the Mekong Delta. Wetlands Ecology and Management 24:231-44.

Nambiar, E., K. Sadanandan, C.E. Harwood and D.K. Nguyen. 2015. Acacia plantations in Vietnam: research and knowledge application to secure a sustainable future. Southern Forests 77:1-10.

Nghiem, N. 2012. Biodiversity conservation attitudes and policy tools for promoting biodiversity in tropical planted forests. Biodiversity and Conservation 22:373-403.

Nguyen, T.H. 2009. Human ecological analysis of land and forest use by the Hmong people for harmonising with the governmental reforestation program in Vietnam. $\mathrm{PhD}$ dissertation, Universität Dresden.

Nguyen, T.H.H, S. Hoshino and S. Hashimoto. 2015. Forest Stewardship Council Certificate for a group of planters in Vietnam: SWOT analysis and implications. Journal of Forest Research 20:35-42.

Nguyen, T.H.H, S. Hoshino, K. Onitsuka and T. Maraseni. 2019. Cost analysis of FSC forest certification and opportunities to cover the costs: A case study of Quang Tri FSC Group in Central Vietnam. Journal of Forest Research 24:1-6.

Nguyen, T.P., V.T. Nguyen, L.P. Quoi and K.E. Parnell. 2016a. Community perspectives on an internationally funded mangrove restoration project: Kien Giang province, Vietnam. Ocean and Coastal Management 119:146-54.

Nguyen, T.P., T.T. Luom and K.E. Parnell. 2017. Mangrove allocation for coastal protection and livelihood improvement in Kien Giang province, Vietnam: Constraints and recommendations. Land Use Policy 63:401-407.
Nguyen, T.T., T. Koellner, Q.B. Le, C.K. Lambini, I. Choi, H. Shin, et al. 2014. An economic analysis of reforestation with a native tree species: The case of Vietnamese farmers. Biodiversity and Conservation 23:811-830.

Nguyen, T.T.P., M. Masuda and S. Iwanaga. 2016b. The effect of forestland allocation to the livelihoods of local people in the North Central Coast of Vietnam: A case in Nam Dong district. Tropics 24:169-180.

Nguyen, T.T.P and M. Masuda. 2018. Land use after forestland allocation and the potential for farm forestry in a mountainous region of Northeast Vietnam. Small-Scale Forestry, Economics and Policy 17:485-503.

Nguyen, V.S. and D.A. Gilmour. 1999. Forest rehabilitation policy and practice in Vietnam: Proceedings of a national workshop. Hanoi, Vietnam: MARD.

Nguyen, V. 1995. Strategy for regreening barren lands and hills in Viet Nam. Hanoi, Vietnam: Ministry of Forestry.

Nguyen, V.B., A. Eyles, D. Mendham, T.L. Dong, D. Ratkowsky, K.J. Evans, et al. 2018. Contribution of harvest residues to nutrient cycling in a tropical Acacia mangium Willd. plantation. Forests 9:577.

Ohlsson, B., S.M. Sandewall, R.K. Sandewall and N.H. Phon. 2005. Government plans and farmers intentions: A study on forest land use planning in Vietnam. Ambio 34:248-255.

Ota, L., J. Herbohn, N. Gregorio, and S. Harrison. 2020. Reforestation and smallholder livelihoods in the humid tropics. Land Use Policy 92:104455.

Paudyal, K., Y.B. Samsudin, H. Baral, B. Okarda, V.T. Phuong, S. Paudel, et al. 2020. Spatial assessment of ecosystem services from planted forests in Central Vietnam. Forests 11:822.

Pham, T.D., N. Kaida, K. Yoshino, X.H. Nguyen, H.T. Nguyen and D.T. Bui. 2018. Willingness to pay for mangrove restoration in the context of climate change in the Cat Ba Biosphere Reserve, Vietnam. Ocean and Coastal Management 163:269-77.

Pham, V.H., V.D. Luu, T.T. Nguyen and O. Koji. 2017. Will restored mangrove forests enhance sediment organic carbon and ecosystem carbon storage? Regional Studies in Marine Science 14:43-52.

Phong, N.T., K.E. Parnell and A. Cottrell. 2017. Human activities and coastal erosion on the Kien Giang Coast, Vietnam. Journal of Coastal Conservation 21:967-979.

Pokorny, B., L. Hoch and J. Maturana. 2010. Smallholder plantations in the tropics-Local people between outgrower schemes and reforestation programmes. Pages 140-70 in J. Bauhus, P. van der Meer and M. Kanninen (eds), Ecosystem Goods and Services from Plantation Forests. London, UK: Earthscan.

Richards, M. 2019. Gender and wood-based value chains in Vietnam. Hanoi, Vietnam: Forest Trends.

Rizzetti, D., K. Swaans, J. Holden, J. Brunner, T. Le. and T. Nguyen. 2018. Assessing opportunities in forest landscape restoration in Quang Tri, Viet Nam. Hanoi, Vietnam: IUCN.

Rudel, T.K, P. Meyfroidt, R. Chazdon, F. Bongers, S. Sloan, H.R. Grau, et al. 2020. Whither the forest transition? Climate change, policy responses, and redistributed forests in the twenty-first century. Ambio 49:74-84.

Šálek, L. and R. Sloup. 2012. Economic evaluation of proposed pure and mixed stands in central Vietnam highlands. Journal of Agriculture and Rural Development in the Tropics and Subtropics 113:21-29.

Sandewall, M., H. Kassa, S. Wu, P.V. Khoa, Y. He and B. Ohlsson. 2015. Policies to promote household-based plantation forestry and their impacts on livelihoods and the environment: Cases 
from Ethiopia, China, Vietnam and Sweden. International Forestry Review 17:98-111.

Sandewall, M., B. Ohlsson, R.K. Sandewall and L.S. Viet. 2010. The expansion of farm-based plantation forestry in Vietnam. Ambio 39:567-579.

Sang, P.M., D. Lamb, M. Bonner and S. Schmidt. 2013. Carbon sequestration and soil fertility of tropical tree plantations and secondary forest established on degraded land. Plant and Soil 362:187-200.

Sikor, T. 2011. Financing household tree plantations in Vietnam: Current programmes and future options. Bogor: CIFOR.

Sikor, T. and J.A. Baggio. 2014. Can smallholders engage in tree plantations? An entitlements analysis from Vietnam. World Development 64:S101-S112.

Sikor, T. and Q.T. Nguyen. 2007. Why may forest devolution not benefit the rural poor? Forest entitlements in Vietnam's Central Highlands. World Development 35:2010-2025.

Simelton, Elisabeth, and B.V. Dam. 2014. Farmers in NE Viet Nam rank values of ecosystems from seven land uses. Ecosystem Services 9:133-138.

Simelton, E.S., D.C. Catacutan, T.C. Dao, B.V. Dam and T.D. Le. 2017. Factors constraining and enabling agroforestry adoption in Viet Nam: A multi-level policy analysis. Agroforestry Systems 91:51-67.

Sowerwine, J.C. 2004. Territorialisation and the politics of highland landscapes in Vietnam: Negotiating property relations in policy, meaning and practice. Conservation and Society 2:97-136.

Socialist Republic of Vietnam (SRV). 2005. Conclusions of the Standing Deputy Prime Minister Nguyen Tan Dung in a review workshop on the implementation of the 5 Million Hectares Reforestation Program and forest protection. Hanoi: Socialist Republic of Vietnam.

Socialist Republic of Vietnam (SRV). 2017. Decision No. 886/ QD-TTG approving target program for sustainable forestry development during 2016-2020 period. Hanoi, Vietnam.

Socialist Republic of Vietnam (SRV). 2020. Báo cáo chiến lược phát triển lâm nghiệp Việt Nam Giai Đoan 2021-2030, tầm nhìn Đến năm 2050. Report on strategy to develop forestry in Vietnam from 2021-2030, with a vision to 2050. Hanoi, Vietnam.

Sunderlin, William D and T.B. Huynh. 2005. Poverty alleviation and forests in Vietnam. Bogor, Indonesia: Center for International Forestry Research.

Thulstrup, A.W. 2014. Plantation livelihoods in central Vietnam: Implications for household vulnerability and community resilience. Norsk Geografisk Tidsskrift-Norwegian Journal of Geography 68:1-9.

Thulstrup, A.W. 2015. Livelihood resilience and adaptive capacity: Tracing changes in household access to capital in central Vietnam. World Development 74:352-362.

Thulstrup, A.W., T. Casse and T.T. Nielsen. 2013. The push for plantations: Drivers, rationales and social vulnerability in Quang Nam province, Vietnam. Pages 71-89 in O. Bruun and T. Casse (eds), On the Frontiers of Climate and Environmental Change: Vulnerabilities and Adaptations in Central Vietnam. Berlin, Germany: Springer.

Tran, C., T.T.Q. Chinh, Y. Zhang and Y. Xie. 2020. Economic performance of forest plantations in Vietnam: Eucalyptus, Acacia mangium, and Manglietia conifera. Forests 11:284.

Tran, L. and K. Brown. 2019. The importance of ecosystem services to smallholder farmers in climate change adaptation: Learning from an ecosystem-based adaptation pilot in Vietnam. Agroforestry Systems 93:1949-1960.
Tran, L.D., R. Doyle, C.L. Beadle, R. Corkrey and N.X. Quat. 2014a. Impact of short-rotation Acacia hybrid plantations on soil properties of degraded lands in central Vietnam. Soil Research 52:271.

Tran, N.T. and T. Sikor. 2006. From legal acts to actual powers: Devolution and property rights in the Central Highlands of Vietnam. Forest Policy and Economics 8:397-408.

Tran, T.T.H., H. van Dijk and S.R. Bush. 2012. Mangrove conservation or shrimp farmer's livelihood? The devolution of forest management and benefit sharing in the Mekong Delta, Vietnam. Ocean and Coastal Management 69:185-193.

Tran, T.T.H., M. Zeller and C.T. Hoang. 2014b. The 'Five Million Hectare Reforestation Program' in Vietnam: An analysis of its implementation and transaction costs, a case study in Hoa Binh province. Quarterly Journal of International Agriculture 53:341-375.

Tran, T.P.H., H. van Dijk and L. Visser. 2014c. Impacts of changes in mangrove forest management practices on forest accessibility and livelihood: A case study in mangrove-shrimp farming system in Ca Mau Province, Mekong Delta, Vietnam. Land Use Policy 36:89-101.

Villamor, G.B., D.C. Catacutan, V.A.T. Truong and L.T. Doan. 2017. Tree-cover transition in northern Vietnam from a gender-specific land-use preferences perspective. Land Use Policy 61:53-62.

van Oosten, C. 2013. Restoring landscapes-governing place: A learning approach to forest landscape restoration. Journal of Sustainable Forestry 32:130627123019006.

Vu, D.H., E.S. Nambiar, L.T. Quang, D.S. Mendham and P.T. Dung. 2014. Improving productivity and sustainability of successive rotations of Acacia auriculiformis plantations in South Vietnam. Southern Forests: A Journal of Forest Science 77:51-58.

Yamanoshita, M.Y. and M. Amano. 2012. Capability development of local communities for project sustainability in afforestation/ reforestation Clean Development Mechanism. Mitigation and Adaptation Strategies for Global Change 17:425-40.

Woo, S.Y., T.T. Hung and P.S. Park. 2011. Stand structure and natural regeneration of degraded forestland in the Northern Mountainous region of Vietnam. Landscape and Ecological Engineering 7:251-261

World Bank. 2010. Socialist Republic of Vietnam: Forest law enforcement and governance. Hanoi, Vietnam: World Bank.

World Bank. 2019. Forest country note-Vietnam. Washington, DC: World Bank.

Zeng, Y., T.V. Sarira, L.R. Carrasco, K.Y. Chong, D.A. Friess, J.S.H. Lee, et al. 2020. Economic and social constraints on reforestation for climate mitigation in Southeast Asia. Nature Climate Change 10:842-844.

Zhunusova, E., T.H.S. Le, J.M. Schroeder, S. Ziegler, M. Dieter and S. Guenter. 2019. Smallholder decision-making on sawlog production: The case of Acacia plantation owners in central Vietnam. Forests 10:969.

Pamela D. McElwee (corresponding author) Department of Human Ecology, Rutgers, The State University of New Jersey, 55 Dudley Road, New Brunswick, NJ 08901 U.S. pamela.mcelwee@rutgers.edu.

Tran Huu Nghi, Tropenbos Vietnam, 1 Đoàn Hũu Trung, Phước Vĩnh, Thành phố Huế, Thửa Thiên Huế, Vietnam. 